
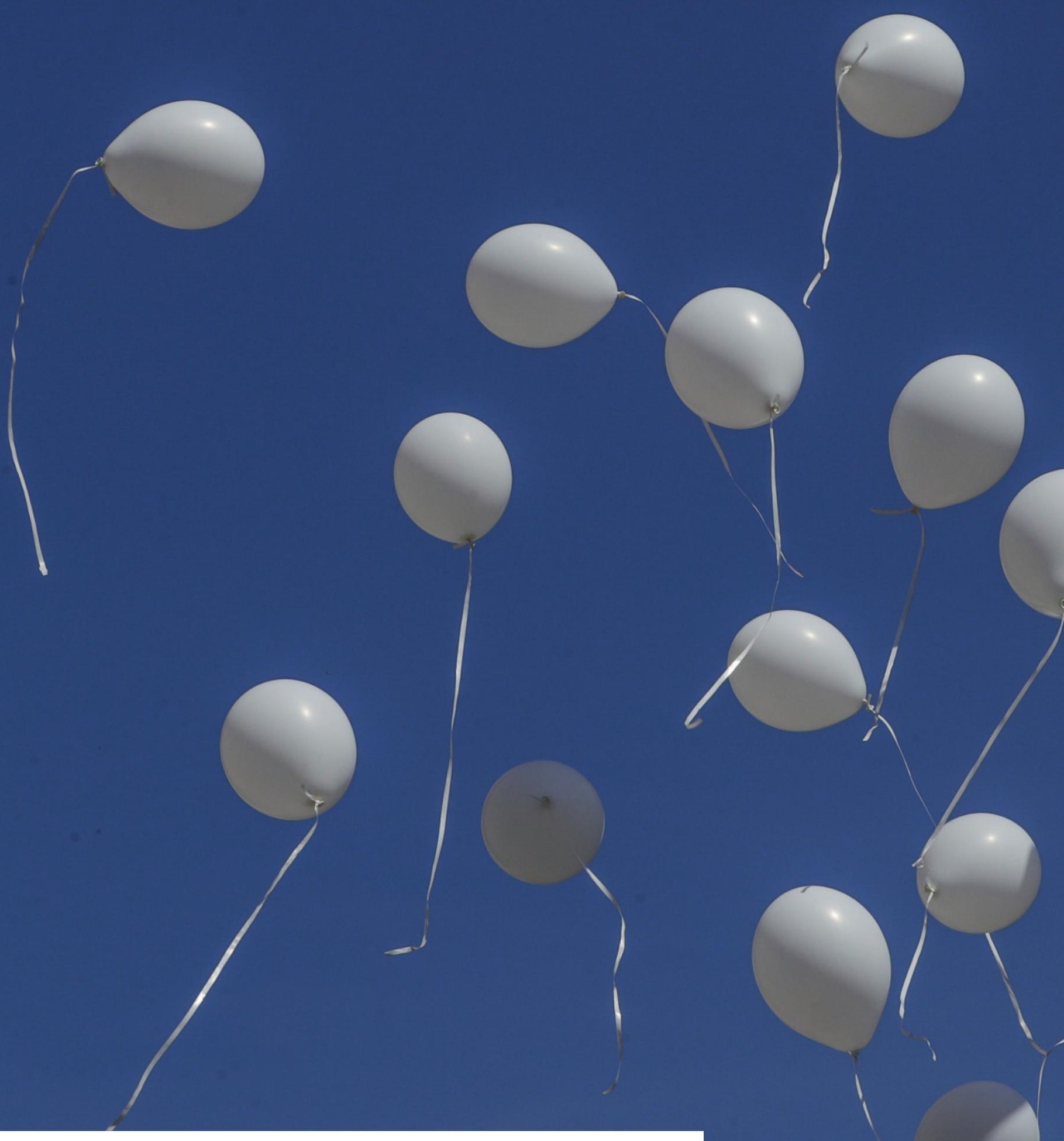

\title{
EERBETOON AAN COLLEGA MET COVID-19
}

BRUSSEL - Medewerkers van het Iris-ziekenhuis lieten eind juni witte ballonnen op ter

nagedachtenis aan hun collega, een verpleegkundige die stierf aan de gevolgen van covid-19.

Ook hielden de collega's een minuut stilte en legden ze witte rozen neer. De verpleegkundige is

niet de enige zorgmedewerker die is overleden aan covid-19 in België en Nederland. Nursing wenst

alle collega's die iemand moeten missen in hun team veel sterkte toe. (Foto: Stephanie Lecocq) 


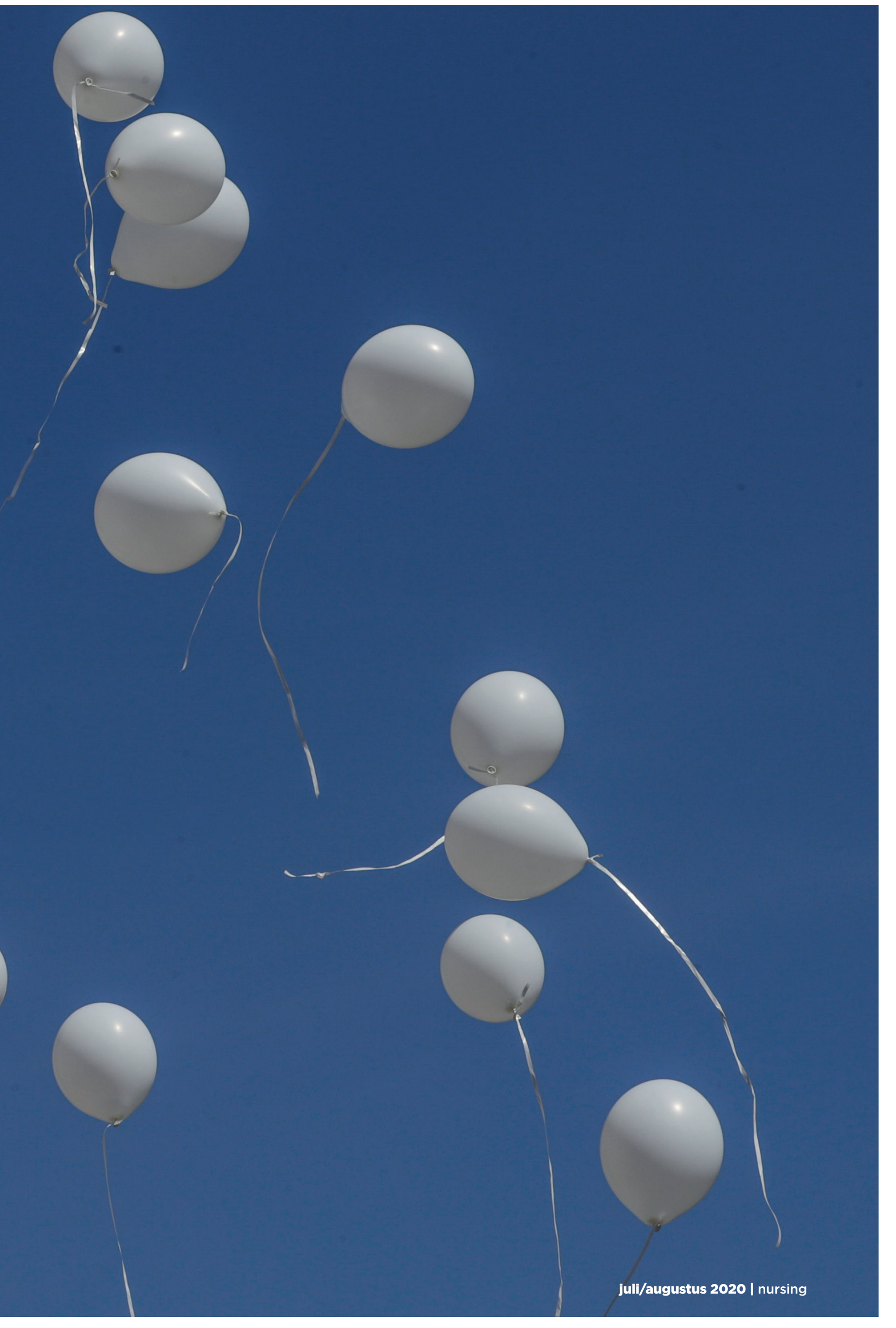

